\title{
Hamerkop (Scopus umbretta) predation on an Augrabies flat lizard (Platysaurus broadleyi)
}

\author{
JAMES BAXTER-GILBERT ${ }^{1 *}$, JULIAN PARSONS², CHARLOTTE BOSTOCK ${ }^{3}$ \& JULIA L. RILEY ${ }^{1}$ \\ ${ }^{1}$ Department of Botany and Zoology, Stellenbosch University, Stellenbosch, 7600, South Africa \\ ${ }^{2}$ Croydon Vineyard Estate, Somerset West, South Africa, 7130 \\ ${ }^{3}$ BBC Bristol, 23 Whiteladies Rd, Bristol, BS8 2LR, UK \\ *Corresponding author e-mail: jx_baxtergilbert@laurentian.ca
}

$\mathrm{O}^{n}$ 27 August 2018 at Augrabies Falls National Park $\left(28.5942^{\circ} \mathrm{S}, 20.3381^{\circ} \mathrm{E}\right)$ we observed an adult Hamerkop (Scopus umbretta) foraging adjacent to the main waterfall along a rock shelf midway down the cliff-side. At 15:37 h we saw the bird capturing and swallowing an Augrabies flat lizard (Platysaurus broadleyi; Fig. 1). This observation is noteworthy as to date the primary predators of Augrabies flat lizards are known to be raptors (e.g. Rock Kestrel, Falco rupicolus, and Booted Eagles, Aquila pennatus) and sand snakes (Psammophis sp.), with other potential predators being mongooses and large arthropods, such as spiders and centipedes (Whiting, 2002; A. Jenkins pers. comm.). Hamerkop, to the best of our knowledge, have not been documented previously to consume reptiles, and as such there have been no previous observations of them eating this specific lizard species. The known diet of Hamerkop consists of frogs, particularly of the genus Xenopus, insects, and fish (Skead, 1953; Liversidge, 1963; Dean \& MacDonald, 1981; Kahl, 1987; Yohannes, et al., 2014).

On the same day as this observation, we had seen hundreds of Augrabies flat lizards living and foraging on the granite rocks and cliffs on either side of the Orange River near the falls. Consequently, for an opportunistic predator these lizards would be a widely-abundant local food source that is easily exploited. Furthermore, this may represent an important ecological link within Augrabies Falls National Park that may have management implications. Previously, attempts have been made to control the blackfly (Simulium spp.) population along the Orange River and within the park through the use of aquatic larvicides (Palmer et al., 1996). Early control measures in 1960's involved the application of DDT, however after widespread negative ecological impacts later applications used the soil bacterium Bacillus thuringiensis var. israelensis as a blackfly larvicide (Palmer et al., 1996). These control programs were undertaken not for human health concerns but rather due to the lost revenue and taxes related to the impact biting flies have on livestock growth and production (Palmer et al., 1996), as well as the general annoyance these swarms have on local human populations. However, the dense blackfly population supports the substantial Augrabies flat lizard population (Branch \& Whiting, 1997). If future efforts are made to reduce blackfly populations along the Orange River this may have

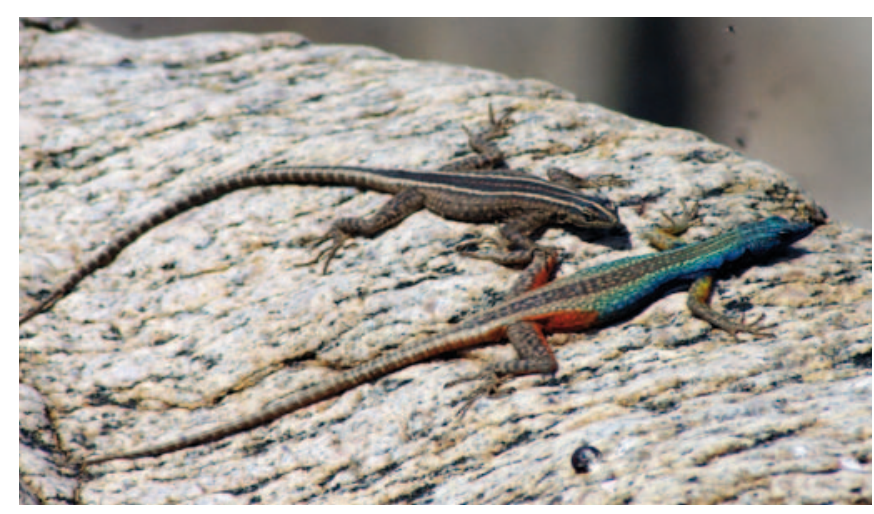

Figure 1. Two Augrabies flat lizards ( $P$. broadleyi) on the granite outcrops alongside the Orange River in Augrabies Falls National Park, Northern Cape, South Africa. The lizard on the left is a female, and the lizard on the right is a male. These lizards congregate around the Orange River at Augrabies Falls to consume blackflies (Simulium spp.), which are also visible within the photo.

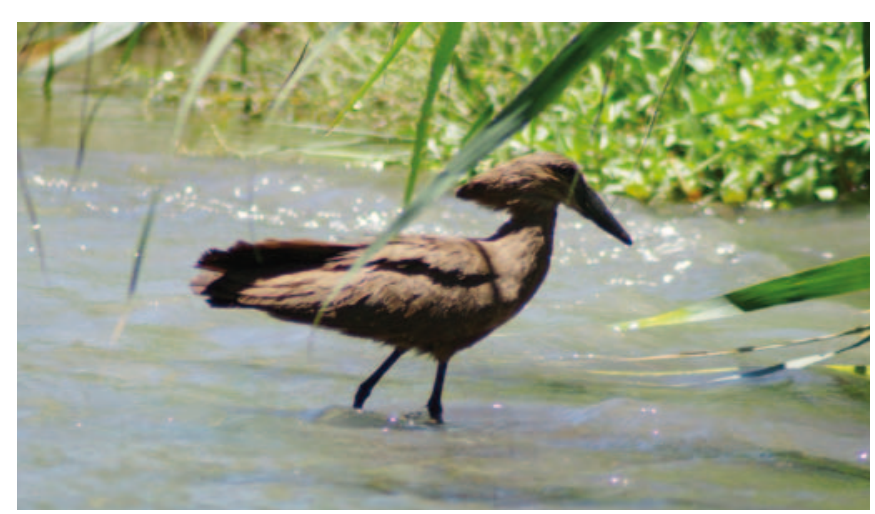

Figure 2. A hamerkop (S. umbretta) foraging in the water at Augrabies Falls National Park, Northern Cape, South Africa.

a ripple effect on the biodiversity of the area. For instance, reducing the food resources of Augrabies flat lizards could, in turn, reduce resources for both specific and opportunistic predators of this lizard species, like Hamerkops.

\section{ACKNOWLEDGMENTS}

We would like to thank Dr. Martin Whiting for his many insights into this charismatic lizard species and advice on this 
Natural History Note, Dr. Peri Bolton for her assistance in the field, the BBC for supporting us during our stay in Augrabies, and of course the wonderful staff at Augrabies Falls National Park for all their help. We wish to acknowledge Julia Riley for the two photographs in this article.

\section{REFERENCES}

Branch, W.R. \& Whiting, M.J. (1997). A new Platysaurus (Squamata: Cordylidae) from the Northern Cape Province, South Africa. African Journal of Herpetology 46: 124-136.

Dean, W.R.J. \& MacDonald, I.A.W. (1981). A review of African birds feeding in association with mammals. Ostrich 52 : 135-155.

Kahl, M.P. (1987). An overview of the storks of the world. Colonial Waterbirds 10: 31-134.

Liversidge, R. (1963). The nesting of the Hamerkop, Scopus umbretta. Ostrich 34: 55-62.

Palmer, R.W., Edwardes, M. \& Nevill, E.M. (1996). Control of pest blackflies (Diptera: Simuliidae) along the Orange River, South Africa: 1990-1995. Onderstepoort Journal of Veterinary Research 63: 289-304.

Skead, C.J. (1953). Hamerkop stomach contents. Ostrich 24:185.

Whiting, M.J. (2002). Field experiments on intersexual differences in predation risk and escape behaviour in the lizard Platysaurus broadleyi. Amphibia-Reptilia 23: 119124.

Yohannes, Y.B., Ikenaka, Y., Nakayama, S.M. \& Ishizuka, M. (2014). Organochlorine pesticides in bird species and their prey (fish) from the Ethiopian Rift Valley region, Ethiopia. Environmental Pollution 192: 121-128.

Accepted: 23 April 2019 